\title{
ANALISIS KEMAMPUAN BERPIKIR KREATIF MATEMATIS SISWA DALAM MENYELESAIKAN SOAL CERITA DI KELAS IV MI AL-KAMIL KOTA TANGERANG
}

\author{
Ika Pratiwi ${ }^{1}$, Aam Amaliyah ${ }^{2}$, Candra Puspita Rini ${ }^{3}$ \\ Universitas Muhammadiyah Tangerang, Kota Tangerang \\ ikaaapratiwiii13@gmail.com, aam.umt@gmail.com, rinicandrapuspita@gmail.com
}

\begin{abstract}
ABSTRAK
Penelitian ini merupakan penelitian kualitatif deskripstif yang bertujuan untuk menganalisis tingkat kemampuan berpikir kreatif matematis siswa kelas IV dalam menyelesaikan soal cerita pada materi KPK dan FPB. Subjek penelitian ini adalah 9 siswa kelas IV MI Al-Kamil. Teknik pengumpulan data yaitu menggunakan observasi, tes kemampuan berpikir kreatif matematis, wawancara dan dokumentasi. Teknik analisis data yang digunakan meliputi reduksi data, penyajian data dan penarikan kesimpulan. Berdasarkan hasil analisis data didapatkan siswa pada kategori tinggi mempunyai kemampuan berpikir kreatif matematis yang baik (kreatif), diantaranya mereka mampu menjawab soal dengan pemikiran yang lancar dan mendetail serta menggunakan hasil pemikirannya sendiri walaupun belum mampu memberikan jawaban dari arah pemikiran yang berbeda-beda. Siswa pada kategori sedang mempunyai kemampuan yang cukup kreatif, sebagian besar mereka menuliskan jawaban hanya saja masih ada kekeliruan sehingga jawaban yang diperoleh masih ada yang kurang lengkap. Siswa pada kategori rendah kurang mampu menggunakan informasi yang mereka peroleh dari soal sehingga menghambat bahkan membuat mereka tidak dapat mengemukakan ide-ide matematisnya sehingga soal tidak terselesaikan dengan baik, selain itu mereka kurang cermat dan teliti dalam menuliskan jawaban. Hal ini dapat diartikan bahwa setiap siswa mempunyai kemampuan berpikir kreatif matematis yang berbeda-beda.
\end{abstract}

Kata kunci: Berpikir Kreatif, Soal Cerita, Kategori Siswa

\section{ABSTRACT}

This research is a descriptive qualitative research that aims to analyze the level of mathematical creative thinking ability of fourth grade students in solving story problems on the KPK and FPB material. The subjects of this study were 9 students of class IV MI Al-Kamil. Data collection techniques are using observation, mathematical creative thinking ability test, interviews and documentation. Data analysis techniques used include data reduction, data presentation and drawing conclusions. Based on the results of data analysis, students in the high category have good mathematical creative thinking skills (creative), including they are able to answer questions with fluent and detailed thinking and use the results of their own thoughts even though they have not been able to provide answers from different directions of thought. Students in the medium category have quite creative abilities, most of them write down answers, it's just that there are still errors so that the answers obtained are still incomplete. Students in the low category are less able to use the information they get from the questions so that it hinders and even makes them unable to express their mathematical ideas so that the questions are not resolved properly, besides that they are less careful and thorough in writing answers. This means that each student has different mathematical creative thinking abilities.

Keywords: Creative Thinking, Story Problems, Student Category

\section{PENDAHULUAN}

Pendidikan merupakan bekal awal dalam meningkatkan kualitas sumber daya manusia, sehingga dituntut untuk terus berkembang dalam memahami ilmu-ilmu yang ada. Ilmu-ilmu tersebut di terapkan ke 
dalam segala aspek kehidupan sehingga siswa dapat menjadi pribadi manusia yang unggul dalam pembelajaran dan masyarakat. Menurut UU RI tentang sisdiknas No.20 Tahun 2003 pasal 1 (Ayat 1) yang menerangkan bahwa: Pendidikan adalah usaha sadar dan terencana untuk mewujudkan suasana belajar dan proses pembelajaran agar peserta didik secara aktif mengembangkan potensi dirinya untuk memiliki kekuatan spiritual keagamaan, pengendalian diri, kepribadian, kecerdasan, akhlaq mulia, serta keterampilan yang diperlukan dirinya, masyarakat, bangsa dan negara.

Dalam dunia pendidikan dari mulai sekolah dasar hingga ke perguruan tinggi mempelajari banyak mata pelajaran, salah satunya mata pelajaran matematika. Matematika sebagai salah satu mata pelajaran di sekolah yang dinilai memegang peranan yang sangat penting karena matematika dapat meningkatkan pengetahuan siswa dengan kemampuan berpikir logis, analitis, sistematis, kritis, dan kreatif serta kemampuan bekerjasama. Dengan demikian, matematika menjadi mata pelajaran yang wajib dipelajari pada setiap jenjang pendidikan.

Didalam pembelajaran matematika, salah satu kemampuan berpikir yang perlu dikembangkan adalah kemampuan berpikir kreatif. Kemampuan berpikir kreatif matematis merupakan kemampuan yang perlu ada pada diri siswa untuk menganalisis permasalahan matematika dari berbagai sudut pandang, kemudian menyelesaikannya dengan kemampuan yang dimiliki serta melahirkan ide-ide kreatif dengan banyak gagasan. Melalui kemampuan berpikir kreatif tentunya siswa dapat mengamati serta mencermati permasalahan matematika lewat berbagai sudut pandang, selanjutnya mengaitkannya dengan pengetahuan yang dimiliki siswa, sehingga siswa dapat mengungkapkan gagasan/ide baru dalam menyelesaikan soal-soal matematika.

Pentingnya melatih siswa untuk berpikir kreatif matematis dalam menyelesaikan suatu masalah termuat dalam (Permendikbud, 2016) menyebutkan bahwa proses pembelajaran pada setiap satuan pendidikan harus diselenggarakan secara interaktif, inspiratif, menyenangkan, menantang, memotivasi siswa untuk berpartisipasi aktif, serta memberikan ruang yang cukup bagi prakarsa, kreatifvitas, dan kemandirian sesuai dengan bakat, minat dan perkembangan fisik serta psikologis siswa. Dengan meningkatnya kemampuan berpikir kreatif matematis akan memberikan ruang yang luas bagi perkembangan potensi siswa seperti mengembangkan minat, mengasah bakat dan kemampuan, serta memberi kepuasan kepada individu untuk mencapai keberhasilan.

Siswa di harapkan mampu mengembangkan kemampuan berpikir kreatifnya dalam menyelesaikan soal cerita. Soal cerita merupakan permasalahan yang dinyatakan dalam bentuk kalimat bermakna dan mudah dipahami. Matematika merupakan persoalan-persoalan yang terkait dengan permasalahan-permasalahan dalam kehidupan sehari-hari yang dapat dicari penyelesaiannya dengan menggunakan kalimat matematika. Selain itu soal cerita juga merupakan soal yang disajikan dalam bentuk cerita pendek. Cerita yang diungkapkan dapat merupakan masalah kehidupan sehari-hari atau masalah lainnya.

Berdasarkan hasil observasi awal dan wawancara dengan guru kelas IV di MI AlKamil dapat diketahui bahwa kemampuan berpikir kreatif matematis siswa masih rendah. Dapat dilihat dari kurangnya antusias siswa dalam menyelesaikan soal-soal 
matematika, karena mereka menganggap soal matematika merupakan soal yang sulit diselesaikan, sehingga berdampak kepada rendah dan menghambat berkembangnya kemampuan berpikir kreatif, jika tidak dibimbing oleh guru, siswa cenderung malas untuk menyelesaikan soal secara mandiri, tidak adanya siswa yang bertanya mengenai cara lain untuk menyelesaikan dan memecahkan masalah sehingga siswa selalu menjawab soal dengan cara yang guru ajarkan, tidak ada keinginan untuk menyelesaikan soal dengan pemikiran sendiri dengan cara dan jawaban yang beragam, di samping itu, guru terbiasa memberikan contoh soal dan penyelesaiannya sehingga ketika siswa menyelesaikan masalahnya, siswa cenderung melakukannya sesuai dengan contoh yang diberikan guru. Oleh karena itu kemampuan berpikir kreatif siswa rendah dan tidak berkembang.

Hal ini sesuai dengan penelitian yang dilakukan oleh (Nurjamilah \& Marlina, 2019), mengenai kemampuan berpikir kreatif siswa dalam menyelesaikan soal matematika. Hasil penelitian menunjukkan, kemampuan berpikir kreatif matematis siswa di kategorikan cukup rendah. Hal tesebut diketahui dari rata-rata persentase semua indikator, hanya ada satu indikator yang melebihi $50 \%$ yaitu pada indikator kelancaran (fluency) sebesar 83,3\%, sedangkan persentase yang paling rendah terdapat pada indikator elaboration $16,7 \%$. Pada soal elaboration, siswa belum mampu memberikan jawaban yang tepat dan sesuai dari soal yang diberikan.

Berdasarkan latar belakang tersebut, mengingat betapa pentingnya siswa untuk memiliki kemampuan berpikir kreatif matematis. Peneliti akan melakukan penelitian untuk mengetahui bagaimana kemampuan berpikir kreatif matematis dalam menyelesaikan soal cerita. Sehingga peneliti ingin meneliti lebih lanjut dengan judul sebagai berikut : "Analisis Kemampuan Berpikir Kreatif Matematis Siswa dalam Menyelesaikan Soal Cerita di Kelas IV MI Al-Kamil Kota Tangerang".

\section{METODE PENELITIAN}

Penelitian ini menggunakan penelitian kualitatif dengan jenis metode penelitian kualitatif deskriptif. Sugiyono berpendapat bahwa metode penelitian kualitatif adalah metode yang berlandaskan pada filsafat postpositivisme, digunakan untuk meneliti pada kondisi obyek yang alamiah, dimana peneliti adalah sebagai instrumen kunci, teknik pengumpulan data dilakukan secara tringulasi (gabungan observasi, wawancara, dokumentasi), analisis data bersifat induktif atau kualitatif dan hasil penelitian kualitatif dapat bersifat temuan potensi dan masalah, keunikan obyek, makna suatu peristiwa, prores dan interaksi sosial, kepastian kebenaran data, konstruksi fenomena, temuan hipotesis (Sugiyono, 2019, h.25).

Model analisis kualitatif yang digunakan adalah model Miles dan Huberman yang meliputi: reduksi data, penyajian data dan penarikan kesimpulan atau verifikasi. Dalam penelitian ini instrumen yang digunakan peneliti yaitu menggunakan tes, wawancara, observasi, dan dokumentasi.

\section{HASIL DAN PEMBAHASAN}

Pembahasan hasil penelitian ini dimaksud untuk mengetahui kemampuan berpikir kreatif matematis siswa dalam menyelesaikan soal cerita di kelas IV MI AlKamil Kota Tangerang. Berdasarkan hasil penelitian pada kelas IV, jumlah subjek sebanyak 9 siswa. Yang akan dinilai berdasarkan 4 indikator kemampuan berpikir 


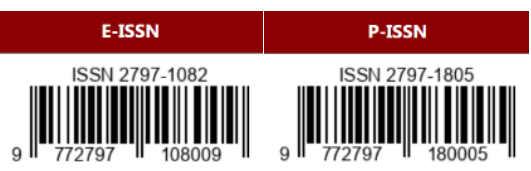

kreatif yaitu kelancaran (fluency), kelenturan (flexibility), keaslian (originality), dan elaborasi (elaboration). Dari 9 siswa yang telah menyelesaikan soal berpikir kreatif matematis, diperoleh bahwa setiap siswa memiliki kemampuan berpikir kreatif matematis yang berbeda-beda. Berikut ini adalah pembahasan lebih lanjut dari masingmasing siswa dengan kemampuan matematis tinggi, kemampuan matematis sedang dan kemampuan matematis rendah.

Siswa dengan kemampuan matematis tinggi, S1 cukup mampu memenuhi soal nomor 1 yaitu indikator kelancaran, kemampuan siswa memberikan banyak cara/jawaban, dilihat dari lembar siswa mampu memberikan dua jawaban dan hasilnya benar. Hal ini sejalan dengan penelitian yang dilakukan oleh Ramadhani \& Nuryanis (2017) yang menyatakan bahwa siswa dengan tingkat kemampuan tinggi mampu menyelesaikan masalah dengan lancar serta dapat memberikan beragam jawaban yang benar. . Pada soal nomor 2 yaitu indikator kelenturan, kemampuan siswa dalam menyelesaikan soal dengan cara yang beragam, dilihat dari lembar jawaban siswa tidak dapat menjawab dengan cara yang beragam, siswa hanya menjawab dengan satu penyelesaian saja. Hal ini sejalan dengan penelitian yang dilakukan oleh Huliatunisa, dkk (2019) menyatakan bahwa ada beberapa subjek masih belum mengerti apa yang menjadi permasalahan, sehingga hanya mampu menemukan satu cara dalam menyelesaikan masalah.

Siswa dengan kemampuan matematis sedang, S4 mampu memenuhi soal nomor 4 dan 5 yaitu indikator elaborasi, kemampuan siswa dalam membuat perincian pada penyelesaian suatu permasalahan. Hal ini sejalan dengan penelitian yang dilakukan oleh
Sopiah, dkk (2020) yang menyatakan pada indikator elaborasi hampir semua siswa mampu menyelesaikan jawaban, meskipun terdapat beberapa siswa yang kurang mampu menyelesaikan jawaban secara terperinci.

Siswa dengan kemampuan matematis rendah, S7 pada soal nomor 3 yaitu indikator keaslian, kemampuan siswa dalam menyelesaikan permasalahan dengan cara yang berbeda dan manarik, dilihat dari lembar jawaban siswa tidak menjawab dengan jawaban yang berbeda dengan hasil pemikiran sendiri. Hal ini sejalan dengan penelitian yang dilakukan oleh Sopiah, dkk (2020) yang menyatakan bahwa pada indikator keaslian siswa yang memiliki kemampuan berpikir kreatif rendah, sedang dan tinggi, mereka cenderung kurang mampu menyelesaikan soal dengan jawaban sendiri atau pemikiran sendiri.

\section{KESIMPULAN DAN SARAN Kesimpulan}

Berdasarkan deskripsi dan analisis hasil penelitian yang telah dilakukan, dapat disimpulkan beberapa hal diantaranya, dari 9 siswa yang sudah diteliti, dengan kategori 3 siswa dengan kemampuan matematis tinggi, 3 siswa dengan kemampuan matematis sedang dan 3 siswa dengan matematis rendah. Siswa pada kategori tinggi mempunyai kemampuan berpikir kreatif matematis yang baik, diantaranya mereka mampu menjawab soal dengan pemikiran yang lancar dan mendetail serta menggunakan hasil pemikirannya sendiri walaupun belum mampu memberikan jawaban dari arah pemikiran yang berbedabeda. Siswa pada kategori sedang mempunyai kemampuan yang cukup kreatif, sebagian besar mereka menuliskan jawaban hanya saja masih ada kekeliruan sehingga jawaban yang diperoleh masih ada yang kurang lengkap. 


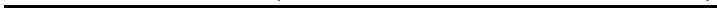

Siswa pada kategori rendah kurang mampu menggunakan informasi yang mereka peroleh dari soal sehingga menghambat bahkan membuat mereka tidak dapat mengemukakan ide-ide matematisnya sehingga soal tidak terselesaikan dengan baik, selain itu mereka kurang cermat dan teliti dalam menuliskan jawaban.

\section{Saran}

Berdasarkan kesimpulan yang telah diuraikan. Maka peneliti mempunyai beberapa saran untuk beberapa pihak yaitu:

\section{Bagi Siswa}

Mengembangkan tingkat berpikir siswa diharapkan lebih aktif dan lebih banyak berlatih menyelesaikan masalah-masalah matematika dari yang penyelesaiannya sederhana sampai kompleks.

\section{Bagi Guru}

Dalam mengajar matematika guru dapat mengembangkan kemampuan berpikir kreatif siswa dengan menerapkan pembelajaran dengan model soal cerita, sehingga dapat meningkatkan kemampuan berpikir kreatif siswa.

\section{Bagi Sekolah}

Memperhatikan kemampuan berpikir kreatif siswa, diharapkan dapat dijadikan referensi untuk menambah media serta buku pembelajaran yang bermutu yang dapat menunjang terlaksananya pembelajaran secara efektif, sehingga dapat mengembangkan kemampuan berpikir kreatif siswa.

\section{Bagi Penulis}

Penulis berharap ada penelitian lagi tentang permasalahan ini agar penelitian ini menjadi lebih sempurna dan menambah wawasan kita semua mengenai kemampuan berpikir kreatif siswa dalam menyelesaikan soal cerita.

\section{DAFTAR PUSTAKA}

Huliatunisa, Y., Wibisana, E., \& Hariyani, L. (2019). Analisis Kemampuan Berpikir Kreatif Matematis Siswa Dalam Menyelesaikan Soal Pemecahan Masalah. Indonesian Journal of Elementary Education. Vol. 1 No. 1, h.56-65.

Ihsan Rahmatilah, M. (2021). Pembelajaran Siswa Sekolah Dasar Warga Kampung Naga Di Masa Pandemi. Berajah Journal, 1(3), 187-192. https://doi.org/10.47353/bj.v1i3.40

Lestari, K. E., \& Yudhanegara, M. R. (2017). Penelitian Pendidikan Matematika. Bandung: PT. Refika Aditama.

Marliani, N. (2015). Peningkatan Kemampuan Berpikir Kreatif Matematis Siswa Melalui Model Pembelajaran Missouri Mathematics Project (MMP). Jurnal Formatif 5 (1), h.14-25.

Ramadhani, D., \& Nuryanis. (2017). Analisis Kemampuan Berpikir Kreatif Matematis Siswa SD Dalam Menyelesaikan Open-Ended Problem. Jurnal Pendidikan Sekolah Dasar. Vol. 4 No. 2, h.54-62.

Sopiah, E. S., Effendi, A., \& Sunaryo, Y. (2020). Analisis Kemampuan Berpikir Kreatif Matematis Siswa Kelas VIII Pada Materi Sistem Persamaan Linear Dua Variabel (SPLDV). Jurnal Keguruan dan Ilmu Pendidikan. Vol. 1 no. 2, h. 1-10.

Sugiyono. (2019). Metode Penelitian Pendidikan. Bandung: Alfabeta cv. 